\title{
Effects on the General Health and Nutritional Status of Children of Partial Replacement of Rice in a Poor Vegetarian Diet by Tapioca Flour
}

\author{
BY SARANYA KUMARI REDDY, T. R. DORAISWAMY, A. N. SANKARAN, \\ M. SWAMINATHAN AND V. SUBRAHMANYAN \\ Central Food Technological Research Institute, Mysore, India
}

(Received 8 Fune 1953)

In previous publications of this series (Subrahmanyan, Murthy $\&$ Swaminathan, I954; Murthy, Swaminathan \& Subrahmanyan, 1954) we reported that: (I) replacement of $25 \%$ of rice in a poor rice diet by tapioca flour did not affect the overall nutritive value of the diet as judged by the growth of young rats, and (2) the retention of calcium in adult human beings on a rice-tapioca diet was greater than that observed on a rice diet; the retention of nitrogen was of the same order on both the diets. The present paper describes the results of an experiment carried out to study the effects on the growth and nutritional status of children of replacing $25 \%$ of rice in a poor rice diet by an equal quantity of tapioca flour.

\section{METHODS}

Subjects. The subjects were girls aged $5^{-1} 7$ years who were residents in an orphanage supported by the Good Shepherd Convent, Mysore. The children were examined clinically and only those free from diseases likely to interfere with the experiment were included. Routine de-worming was done in order to eliminate possible disturbances in the digestion and absorption of food.

Physical measurements and clinical assessment. Initial heights were recorded to the nearest $0.25 \mathrm{in}$. Weights were recorded to the nearest $0.5 \mathrm{lb}$. and, as far as possible, with the same clothing and at about the same time of the day. Hip widths were recorded to the nearest $\frac{1}{8}$ in. Nutritional status was assessed according to the scorecard worked out by the Indian Council of Medical Research: Nutrition Advisory Committee (1948). On the basis of the above data the subjects were allotted at random by a statistician into two groups, so that average age, height, weight and nutritional status in both the groups were almost the same. One group, receiving the usual orphanage diet, served as the control, while the other group which served as the experimental group received a similar diet with the difference that $2 \mathrm{oz}$. of rice $(25 \%$ of the rice in the diet) were replaced by $2 \mathrm{oz}$. of tapioca flour. The experiment lasted for a period of 6 months.

In addition to recording height, weight, hip width and nutritional status, the following laboratory investigations were carried out at the beginning, and at the end of the experiment: (I) haematological studies (red blood-cell count using Neubauer's haemocytometer and haemoglobin using the Sahli-Adam haemometer), and (2) serum protein (total protein, albumin and globulin according to Howe's (I92I) method). 
Pattern and nutritive value of the diets. The diet supplied in the orphanage hostel was fairly typical of diets consumed in many parts of southern India, consisting mainly of cereals and containing only small quantities of pulses and vegetables, with little or no milk, fat, fleshy foods or fruits. A dietary survey lasting over a period of $\mathrm{I}$ week was conducted and data about food consumed were obtained. Intake per consumption unit or 'man value' per day was calculated using the international scale of family coefficients (League of Nations Health Organization, 1932). The pattern of the diets consumed by the control and experimental groups is given in Table $\mathrm{r}$. The nutritive value of the

Table I. Pattern of diets consumed daily by Indian orphanage children on a poor vegetarian diet containing rice, and with the rice partly replaced by tapioca flour

\begin{tabular}{|c|c|c|c|c|}
\hline & \multicolumn{2}{|c|}{ Rice diet } & \multicolumn{2}{|c|}{ Rice-tapioca diet } \\
\hline Foodstuff & $\begin{array}{l}\text { Individual } \\
\text { intake } \\
\text { (oz.) }\end{array}$ & $\begin{array}{l}\text { Intake per } \\
\text { consumption } \\
\text { unit* } \\
\text { (oz.) }\end{array}$ & $\begin{array}{l}\text { Individual } \\
\text { intake } \\
\text { (oz.) }\end{array}$ & $\begin{array}{l}\text { Intake per } \\
\text { consumption } \\
\text { unit* } \\
\text { (oz.) }\end{array}$ \\
\hline Raw milled rice & $8 \cdot 0$ & $10 \cdot 0$ & 6.0 & $7 \cdot 5$ \\
\hline Ragi (Eleusine coracana) & $I \cdot 4$ & $\mathrm{I} \cdot 75$ & $\mathrm{I} \cdot 4$ & $I \div 75$ \\
\hline Tapioca flour or soji & - & - & $2 \cdot 0$ & $2 \cdot 5$ \\
\hline $\begin{array}{l}\text { Pulses (red gram dhal } \\
\text { and horse gram) }\end{array}$ & 0.6 & 0.75 & 0.6 & 0.75 \\
\hline Vegetablest & 0.8 & $I \cdot 0$ & 0.8 & $I \cdot 0$ \\
\hline Oils and fats & 0.3 & 0.375 & 0.3 & 0.375 \\
\hline Jaggery & 0.6 & 0.75 & 0.6 & 0.75 \\
\hline Common salt (crude) & 0.25 & 0.3 & 0.25 & 0.3 \\
\hline
\end{tabular}

diets was calculated using the figures given by Aykroyd, Patwardhan \& Ranganathan (195I) for the chemical composition of different foods. These data, together with the recommended dietary allowances for children of similar age groups suggested by the Nutrition Advisory Committee, Indian Council of Medical Research (Aykroyd et al. I95 I), are given in Table 2. It will be seen that the intake of calories, protein and almost all other nutrients fell short of the recommended allowances. Since the aim of the experiment was to study existing conditions, no attempt was made to make good the deficiencies in any way.

Preparation of the food and feeding of the children under experiment. The subjects were fed three times a day, namely in the morning (breakfast), at noon (lunch) and at night (dinner). Breakfast consisted mainly of cooked rice with a spicy preparation (chutney) made out of dhal, chillies and salt. Lunch consisted of cooked cereals, and a vegetable soup (sambar) containing smail quantities of vegetables, dhal, tamarind, chillies and salt. Dinner consisted of a savoury preparation (uppittu) from broken rice or tapioca soji or an unleavened cake (dosai) made out of rice or tapioca flour, small quantities of cooked rice and chutney. To avoid possible mingling of children of one group with the other, they were fed in two different compartments in the dining hall and the meals of the children were supervised by a matron. All the subjects in the experimental group relished the tapioca preparations. None of the children in either group had any digestive trouble during the experiment. 
Table 2. Average daily intake of different nutrients by the children, compared with standard recommended allowances

$\begin{array}{lccc}\text { Nutrient } & \text { Rice diet } & \begin{array}{c}\text { Rice-tapioca } \\ \text { diet }\end{array} & \begin{array}{c}\text { N.A.C.* } \\ \text { standards }\end{array} \\ \text { Calories (Cal.) } & 1188 & 1170 & 2000 \\ \text { Protein (g) } & 24.3 & 21 \cdot 0 & 57 \\ \text { Fat (g) } & 11 \cdot 3 & 11 \cdot 3 & - \\ \text { Calcium (as Ca) (g) } & 0.31 & 0.36 & 1-1 \cdot 5 \\ \text { Phosphorus (as P) (g) } & 0.46 & 0.48 & - \\ \text { Iron (as Fe) (mg) } & 8 \cdot 7 & 9 \cdot 2 & \text { 10 to 30 } \\ \text { Vitamin A value (i.u.) } & & & \\ \text { As carotene } & 2243 & 2243 & 3000-4000 \\ \text { As vitamin A } & - & - & - \\ \text { Thiamine (mg) } & 0.31 & 0.33 & 0.5-1 \cdot 0 \\ \text { Nicotinic acid (mg) } & 3.9 & 3.5 & 12 \dagger \\ \text { Riboflavin (mg) } & 0.2 & 0.17 & 1.8 \dagger \\ \text { Ascorbic acid (mg) } & 17 & 17 & 30-50\end{array}$

Recommendations of the Indian Council of Medical Research: Nutrition Advisory Committee (Aykroyd et al. 195 I, see text, p. I8).

$\dagger$ Recommendations of (U.S.A.) National Research Council: Food and Nutrition Board (r948).

RESULTS

Of the ninety-six children originally selected for the experiments the data for twentythree children (thirteen from the experimental group and ten from the control group) who were I 3 years and above at the beginning of the experiment, have been excluded on account of the accepted erratic hormonal effect in individuals during the adolescent period. Both the initial and final measurements were not available for six children in the experimental group and for two children in the control group. On account of difficulty in getting blood, analysis for total protein, albumin and globulin content of serum could be made on only a few children from each group.

Table 3 gives the initial frequency distributions for age, height, weight and

Table 3. Initial frequency distributions of age, height, weight and nutritional score of the children

\begin{tabular}{|c|c|c|c|c|c|}
\hline \multicolumn{3}{|c|}{ Age } & \multicolumn{3}{|c|}{ Height } \\
\hline $\begin{array}{c}\text { Age } \\
\text { (years) }\end{array}$ & $\begin{array}{l}\text { Control } \\
\text { group, } \\
\text { no. of } \\
\text { children }\end{array}$ & $\begin{array}{l}\text { Experi- } \\
\text { mental } \\
\text { group, } \\
\text { no. of } \\
\text { children }\end{array}$ & $\begin{array}{l}\text { Height } \\
\text { (in.) }\end{array}$ & $\begin{array}{l}\text { Control } \\
\text { group, } \\
\text { no. of } \\
\text { children }\end{array}$ & $\begin{array}{l}\text { Experi- } \\
\text { mental } \\
\text { group, } \\
\text { no. of } \\
\text { children }\end{array}$ \\
\hline $\begin{array}{l}6 \text { and } \\
\text { below }\end{array}$ & 6 & 4 & $\begin{array}{l}30 \cdot 25-35 \cdot 00 \\
35 \cdot 25-40 \cdot 00\end{array}$ & $\begin{array}{l}4 \\
2\end{array}$ & $\begin{array}{l}2 \\
2\end{array}$ \\
\hline $7-8$ & 2 & 5 & $40 \cdot 25-45 \cdot 00$ & 10 & 7 \\
\hline 9-ro & 16 & 9 & $45 \cdot 25-50 \cdot 00$ & 13 & 9 \\
\hline $11-12$ & 12 & I I & $\begin{array}{l}50 \cdot 25^{-55} \cdot 00 \\
55 \cdot 25^{-60} \cdot 00\end{array}$ & $\begin{array}{l}4 \\
2\end{array}$ & $\stackrel{9}{-}$ \\
\hline
\end{tabular}

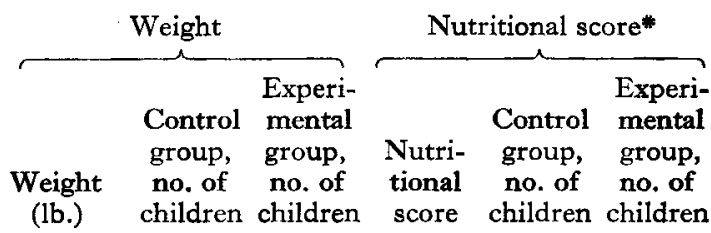

Total 36 29 35 29 25 and below $25 \cdot 5-35 \cdot 0$ $35 \cdot 5-45 \cdot 0$ $45^{\circ}-55^{\circ} 0$ $55^{\circ}-65^{\circ} \circ$ $65^{\circ}-75^{\circ} \circ$

* According to recommendations of the Indian Council of Medical Research: Nutrition Advisory Committee (1948). 
nutritional score. It will be seen from the table that the two groups were fairly balanced in respect of these four characters.

Table 4 gives the initial and final average values of the various characters of the control and experimental groups, together with the results of the test of significance.

Table 4. Average values of the initial and final measurements of the children in the control and experimental groups

\begin{tabular}{|c|c|c|c|c|c|c|c|c|c|c|}
\hline \multirow[b]{2}{*}{ Character } & \multicolumn{4}{|c|}{ Control group (rice diet) } & \multicolumn{4}{|c|}{$\begin{array}{l}\text { Experimental group } \\
\text { (rice-tapioca diet) }\end{array}$} & \multirow{2}{*}{\multicolumn{2}{|c|}{$\begin{array}{c}\text { Difference in } \\
\text { increase } \\
\text { (experimental- } \\
\text { control) }\end{array}$}} \\
\hline & $\begin{array}{l}\text { No. of } \\
\text { children }\end{array}$ & $\begin{array}{c}\text { Initial } \\
\text { value }\end{array}$ & $\begin{array}{l}\text { Final } \\
\text { value }\end{array}$ & Increase & $\begin{array}{l}\text { No. of } \\
\text { children }\end{array}$ & $\begin{array}{l}\text { Initial } \\
\text { value }\end{array}$ & $\begin{array}{l}\text { Final } \\
\text { value }\end{array}$ & Increase & & \\
\hline Age (years) & 36 & $9 \cdot 2$ & - & 一 & 29 & 9.4 & - & - & & - \\
\hline Height (in.) & 35 & $45 \cdot 74$ & $46 \cdot 40$ & $0 \cdot 66$ & 29 & $46 \cdot 50$ & $47^{\prime} \cdot 18$ & 0.68 & 0.02 & $\pm 0 \cdot 12$ \\
\hline Weight (lb.) & 36 & $42 \cdot 6 x$ & 43.68 & I.07 & 29 & $44 \cdot 10$ & $45 \cdot 40$ & $\mathrm{I} \cdot 30$ & 0.23 & $\pm 0 \cdot 56$ \\
\hline Hip width (in.) & 35 & $6 \cdot 98$ & 7.09 & 0.11 & 29 & $7 \cdot 21$ & $7 \cdot 27$ & 0.06 & -0.05 & \pm 0.03 \\
\hline Haemoglobin (g/100 ml. blood) & 36 & II. 44 & 10.74 & $-0 \cdot 70$ & 27 & $11 \cdot 36$ & II 2 I & -0.15 & 0.55 & \pm 0.28 \\
\hline Red blood cells (106/cu.mm) & 35 & $4 \cdot 22$ & $4: 40$ & $0: 18$ & 28 & $4 \cdot 16$ & $4 \cdot 25$ & 0.09 & -0.09 & \pm 0.09 \\
\hline Nutritional scoref & 35 & $4 \cdot 5$ & $4 \cdot 9$ & 0.4 & 29 & $4 \cdot 9$ & $5 \cdot 7$ & 0.8 & 0.4 & \pm 0.3 \\
\hline Serum protein $(\mathrm{g} / 100 \mathrm{ml})$. & 7 & $7 \cdot 0$ & $7 \cdot 5$ & 0.5 & 7 & $6 \cdot 8$ & $7 \cdot 2$ & 0.4 & -0.1 & $\pm 0 \cdot 1$ \\
\hline Albumin $(\mathrm{g} / \mathrm{r} 00 \mathrm{ml})$ & 5 & $4 \cdot 5$ & 47 & 0.2 & 7 & 4.2 & $4 \cdot 6$ & 0.4 & 0.2 & \pm 0.3 \\
\hline Globulin (g/100 ml.) & 5 & 2.7 & $2 \cdot 7$ & 0.0 & 7 & $2 \cdot 6$ & $2 \cdot 6$ & 0.0 & -0.0 & \pm 0.4 \\
\hline
\end{tabular}

* Significant at $P=0.05$.

$\uparrow$ According to recommendations of the Indian Council of Medical Research: Nutrition Advisory Committee (1948).

For the purpose of statistical analysis, the increases in the different characters at the end of the experiment over their initial values were computed for each child for whom both the readings were available. It will be seen from Table 4 that, excepting haemoglobin, there was no significant difference in the characters resulting from the two diets. The haemoglobin content of the blood decreased at the end of the experiment in both groups but the decrease was significantly less $(P<0.05)$ in the experimental group than in the control group. The results obtained would indicate that $25 \%$ of rice in poor vegetarian rice diets could be replaced by an equal quantity of tapioca flour without affecting adversely the health of the children.

\section{SUMMARY}

I. A feeding experiment lasting for a period of 6 months was carried out in a girls' orphanage in Mysore to evaluate the effect on the growth and nutritional status of children between 4 and 12 years of age of replacing $25 \%$ of the rice in a poor vegetarian rice diet by tapioca flour.

2. Data on the weight, height, hip width, nutritional status, haemoglobin, red bloodcell count and serum proteins were obtained at the beginning and at the end of the experiment for a group of children receiving the rice-tapioca diet and for a control group of similar children receiving the rice diet. The results showed that there was no significant difference between the two groups in respect of any of the characteristics studied except haemoglobin. Though the haemoglobin content of the blood decreased in both the groups, the decrease was significantly less $(P<0.05)$ in the experimental group than in the control group. 
We are grateful to Professor K. K. Mathen, All-India Institute of Hygiene and Public Health, Calcutta, for help in classifying the children into two groups and Mr H. B. N. Murthy for help in the estimation of serum proteins.

Our thanks are also due to the authorities of the Good Shepherd Orphanage for providing us every facility for carrying out the experiment described in this paper.

\title{
REFERENCES
}

Aykroyd, W. R., Patwardhan, V. N. \& Ranganathan, S. (1951). Hlth Bull., Simla, no. 23. Howe, P. E. (1921). F. biol. Chem. 49, rog.

Indian Council of Medical Research: Nutrition Advisory Committee (1948). Report of the Scientific Advisory Board for the Year 1948. New Delhi: Indian Council of Medical Research.

League of Nations Health Organization (1932). Quart. Bull. Hlth Org. L.o.N. I, 479.

Murthy, H. B. N., Swaminathan, M. \& Subrahmanyan, V. (1954). Brit. F. Nutr. 8, I I.

National Research Council: Food and Nutrition Board (1948). Repr. nat. Res. Coun., Wash., no. I29, p. I3.

Subrahmanyan, V., Murthy, H. B. N. \& Swaminathan, M. (1954). Brit. F. Nutr. 8, I.

\section{Protein Katabolism and Oxygen Consumption during Starvation in Infants, Young Adults and Old Men}

\author{
By R. A. McCANCE AND W. M. B. STRANGEWAYS \\ Medical Research Council Department of Experimental Medicine, University of \\ Cambridge
}

(Received I9 Fune 1953)

In their work on the partition of nitrogen in the urine of newborn breast-fed infants Barlow \& McCance (I948) found that the total nitrogen excreted during the first $48 \mathrm{~h}$ of life was of the order of $30 \mathrm{mg} / \mathrm{kg}$ body-weight $/ 24 \mathrm{~h}$. During this time the breast-fed infant obtains very little food and fluid and is in a state of physiological hydropenia and of almost complete starvation. Barlow \& McCance pointed out that Cathcart's (I907) and Benedict's (1915) work had shown that the starving adult, with an unrestricted water intake, excreted about $140 \mathrm{mg} \mathrm{N} / \mathrm{kg}$ body-weight $/ 24 \mathrm{~h}$. Although this was a large difference they did not claim that it represented a difference in the nitrogen katabolized because it was known from previous work (McCance \& Widdowson, 1947) that there was usually some retention of nitrogen over the first 2 days of life, and this had not been measured.

A re-examination of this evidence in 1949 suggested that the nitrogen katabolized by infants per $\mathrm{kg}$ body-weight in the first $48 \mathrm{~h}$ of life really was smaller than that katabolized by fasting adults. This was felt to be curious since Benedict $\&$ Talbot (19I5) had found that the calorie output of resting infants was $48 \mathrm{Cal} / \mathrm{kg} / 24 \mathrm{~h}$, whereas that of adults was only ${ }_{3} \mathrm{Cal} / \mathrm{kg} / 24 \mathrm{~h}$. Little help in the resolution of this difficulty could be obtained from the literature. Schlossmann \& Murschhauser (19r4) appeared to have been two of the few, if not the only, investigators to have measured the nitrogen katabolism and the calorie expenditure of the same starving baby. In 